\title{
INFLUENCE OF AGRICULTURAL DEVELOPMENTS ON NET PRIMARY PRODUCTIVITY (NPP) IN THE SEMI-ARID REGION OF INDIA: A STUDY USING GLOPEM MODEL
}

\author{
Madhav D. Gholkar ${ }^{\mathrm{a}}$ *, Sheshakumar Goroshi ${ }^{\mathrm{a}}$, Raghavendra P. Singh ${ }^{\mathrm{a}}$, Jai Singh Parihar ${ }^{\mathrm{a}}$ \\ ${ }^{\text {a }}$ Space Applications Centre, Indian Space Research Organization, Ahmedabad, India \\ *madhav.dg@gmail.com
}

KEY WORDS: Agricultural net primary productivity, Agricultural mechanization, Semi-arid region, Irrigated area, Fertilizer use

\begin{abstract}
:
The present study aims to assess the effect of agricultural developments on inter-annual variations in the agricultural Net Primary Productivity (NPP) of selected districts of the semi-arid region of India by using GloPEM model. Advancements in farming practices have been contributing to the increase of net primary productivity, which ultimately leads to increase in the agricultural production. The study shows that increase in the gross irrigated area, fertilizer consumption, use of high yielding crop varieties and adoption of agricultural mechanization in terms of tractors and irrigation pumps have contributed significantly in the increase in agricultural NPP in the semi-arid region of India. The agricultural NPP of the semi-arid region of India has shown a very good correlation with the gross irrigated area $\left(R^{2}=0.668\right)$ and fertilizer use $\left(R^{2}=0.701\right)$. The anthropogenic factors influencing the agricultural NPP were grouped in 3 major Factor Components (FC) (eigenvalues $>1$ ) as: FC1-nutrients application, FC2-irrigation potential and agricultural mechanization (irrigation pumps and tractors) and irrigated area while FC3-cultivated area and area under high yielding crop varieties. The study showed that most of the semi-arid region of India has a good agricultural production potential which needs to harness by increasing the supply of irrigation water, promoting agricultural mechanization and adoption of integrated nutrient management approach.
\end{abstract}

\section{INTRODUCTION}

\subsection{Background}

Agriculture has changed significantly with the advances in science and technology. In recent years, the use of chemical fertilizers, high yielding crop varieties and adoption of farm mechanization have proven to be effective ways to increase agricultural productivity (Soni and Ou, 2012). As one of the largest agrarian economies, agricultural sector holds the basis of socio-economic lifestyle of India. The diverse climatic conditions of the country facilitate a wide spectrum of crops, plantations, allied activities and services. It is necessary to entrap the vast agricultural potential of the country to improve and enhance the country's agricultural sector (DIA, 1997).

The reckoning events of climate change and their notable impacts on the global environment emphasizes that some of the regions will experience the adverse changes such as augmented drought and/or flooding events, while others may experience the climatic conditions more favorable to the agricultural production (IPCC, 2007). In case of India, global circulation model scenarios predicted warmer and wetter conditions as a result of climate change. However, it is also proposed that the increase in the temperature and $\mathrm{CO}_{2}$ may lead the increase in the productivity of irrigated areas of the country (Aggarwal and Mall, 2002). Thus, in general, Indian agriculture is likely to be affected by climate change, particularly in the water stressed semi-arid region, unless mitigation practices are not implemented properly. Though today India has become self sufficient in agricultural production, the enormous population growth of the country demands higher food production in near future. The increasing demand of food can be achieved mainly by increasing the agricultural productivity as the land under agricultural activities may remain more or less unchanged. So, it is necessary to explore the country's terrestrial productivity to analyze the regional agricultural status, its susceptibility to the climate change and potential mitigation measures to overcome the forthcoming possibilities of harsh climatic conditions.

Terrestrial Net Primary Productivity (NPP) is the quantifiable and fundamental ecological variable in biosphere functioning and is needed for assessing the carbon balance at regional and global scales (Chhabra and Dadhawal, 2004). Terrestrial NPP provides an indicative measure of the integrated effects of climate and anthropogenic interventions in the vegetative systems (Hemming et al., 2013). Net primary productivity is the uptake flux, in which carbon from the atmosphere is sequestrated by plants through the balance between photosynthesis and plant respiration (Ahlström et al., 2012). Estimation of NPP can be used as an indicator to assess the changes in the crop yield, forest productivity and other socioeconomical activities and their impacts on the local environment. Determining the trend and variability of agricultural NPP and its response to the climate change is critical for understanding the changes in the regional carbon cycle in response to temperature, precipitation and other anthropogenic factors such as increase/decrease in irrigation potential, fertilization, mechanization etc. which governs the agricultural productivity.

The World Bank has characterized India as the 'transforming agricultural world' (Jewitt and Baker, 2012). The Indian 
agricultural sector is influenced by more than the changing climatic conditions (O’Brien et al., 2004) and human interventions in the ecological process is one of the main reasons. Anthropogenic activities in natural ecosystems alter the ecological energy flows. Prasad and Badarinth (2004) estimated the Human Appropriation of Net Primary Productivity (HANPP) in India for the period of 37 years (1961-1998). They reported that overall about $42 \%$ of the available NPP (forest and agriculture) is appropriated. HANPP refers to the appropriation of biomass by harvesting and/or by altering the land productivity through land use changes. To meet the growing population demand the human appropriation of agricultural NPP can be increased by increasing irrigation facilities, proper use of fertilizers and high yielding crop varieties and plant protection measures.

Recent studies for the period of 1981 to 2000 for the estimation of terrestrial NPP for India showed a positive increase of about 8.5\% per decade (Singh et al., 2011; Nayak et al., 2013). The study conducted by Singh et al. (2011) highlighted that the most of the area under the semi-arid region of India shows higher positive growth in the NPP over the period of 19812000. Thus the study was conducted to evaluate the anthropogenic influence on agricultural NPP of the semi arid region of India.

\subsection{Factors Influencing Agricultural Net Primary Productivity}

Changes in NPP could arise due to anthropogenic effects and climate change, and directly affect human and animal food supplies (Chhabra and Dadhawal, 2004). Though the climatic parameters are the main governing factors for the NPP of a region, human interventions and developments play key role in the variations of agricultural NPP.

The factors which directly influence the agricultural NPP are precipitation, atmospheric temperature, solar radiation, atmospheric $\mathrm{CO}_{2}$, productivity of soil, irrigation water, fertilizer and pesticides while the factors influencing indirectly are agricultural machineries and the electric and diesel pumps for irrigation.

Agricultural mechanization in terms of tractors and tillage equipments helps to provide better soil tilth to a depth so plants can develop a root system which will physically support the plant and also allow the extraction of sufficient moisture and nutrients for better plant growth (Keen et al. 2013). Irrigation pumps (Electric and Diesel operated) facilitate timely supply of water for the cropping system as per the requirement. Thus, agricultural mechanization indirectly assists the increase in agricultural NPP.

Bala et al. (2013) generated single and multivariate NPP time series for 25 years by considering climatic parameters such as temperature, precipitation, surface solar radiation, soil water and atmospheric $\mathrm{CO}_{2}$. However, total observed NPP (forest + non-forest) of India did not showed firm casual relationships with climatic parameters individually except with the atmospheric $\mathrm{CO}_{2}$. Thus, the increase in NPP is primarily associated with an increase in the mean atmospheric $\mathrm{CO}_{2}$.

The recent studies (Bala et al., 2013; Nayak et al., 2013) reported that the NPP associated with the cropland areas have a major contribution in the increasing total NPP of India. This highlights the advances in land use management practices and human interventions in the agro-ecosystems have played main role in the increasing agricultural NPP of the country.

The correlation between the NPP growth of non-forest areas of India with the net irrigated area showed positive correlation with $r=0.77$ and $\mathrm{R}^{2}=0.59$ (Bala et al., 2013). But in actual case, while correlating the total annual non-forest NPP which is mainly resulting from the agricultural cropland NPP with only the net irrigated area reduces its applicability as there are some agricultural areas irrigated more than once in a year which also adds up the total annual agricultural NPP of a region. So, gross irrigated area and gross cultivated area were considered in this analysis.

Earlier studies till the date were conducted over the vast diversified geographical area of India. It was observed that the mean NPP data having higher values of standard deviations and wider decadal relative deviations in the NPP range from $-10 \%$ to $+40 \%$ at different regions of India (Singh et al. 2011). Hence, this study was focused on the selected districts of the semi-arid region of the country where higher NPP growth (greater than 15\%) was recorded.

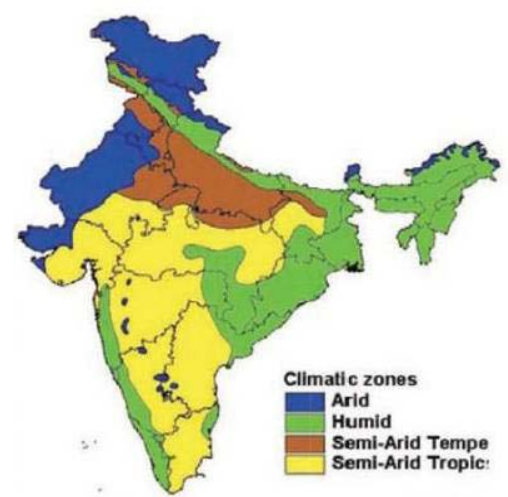

Figure 1(a). Major climatic zones of India (NICA, 2011)

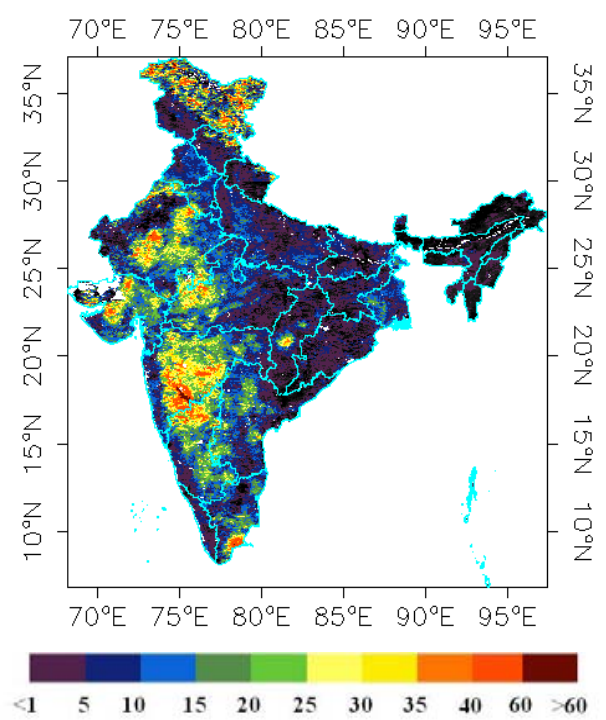

Figure 1(b). Decadal changes in mean NPP represented as relative deviations (\%) for the period 1981-1990 to 1991-2000 


\subsection{Study Area}

India's almost $53.4 \%$ land area comprises of arid and semi-arid regions (NATCOM, 2004). The northern semi-arid regions in India (Figure 1a) comprise largely of the eastern Rajasthan, Haryana, parts of Punjab and Gujarat while, the Southern semi-arid regions are in the rain shadow of the Western Ghats covering central Maharashtra, northern parts of Karnataka and western parts of Tamil Nadu and Andhra Pradesh.

The semi-arid region of India characterizes of annual rainfall of about 25 to $80 \mathrm{~cm}$. Low and erratic rainfall often come in a few heavy storms of short duration resulting in high runoff, instead of replenishing the ground water. Relatively extreme temperatures and intense solar radiation makes these regions the most vulnerable regions in India (CED, 2011). Thus, irrigation with surface or ground water is inevitable for growing crops in the arid and semi-arid zones.

The state-wise districts showing greater than 15\% NPP increase were considered for this study. Total 31 districts from 5 states were selected Figure $2 \mathrm{~b}$ highlights the study area of selected districts. Out of selected 31 districts 15 districts are from Maharashtra, 10 from Karnataka, 6 from Madhya Pradesh and 5 each from Gujarat and Rajasthan. During the study period some of the selected districts were split to form new districts, so such districts were combined and considered as a single region for the ease of analysis.

Table 1. State-wise districts selected (agricultural NPP increase $\geq 15 \%$ ) from the semi-arid region of India

\begin{tabular}{|c|c|c|}
\hline Maharashtra (15) & Karnataka (10) & Madya Pradesh (6) \\
\hline Nasik & Bijapur-Bagalkot & Ujjain \\
\hline Dhule-Nandurbar & Gulbarga & Mandsaur-Neemuch \\
\hline Jalgaon & Belgaum & Ratlam \\
\hline Ahmadnagar & Dharwad-Gadag-Haveri & Shajapur \\
\hline Solapur & Chitradurga-Davangere & Rajgarh \\
\hline Sangli & Tumkur & \\
\hline Aurangabad- Jalna & & Gujarat (5) \\
\hline Parbhani-Hingoli & Rajasthan (4) & Amreli \\
\hline Beed & Ajmer & Bhavnagar \\
\hline Nanded & Jhalawar & Jamnagar \\
\hline Osmanabad-Latur & Kota-Baran & Rajkot \\
\hline & Tonk & Surendranagar \\
\hline
\end{tabular}

\section{METHODOLOGY}

\subsection{Extraction of District wise Agricultural NPP}

Long term (1981 to 2000) NOAA-AVHRR (Advanced Very High Resolution Radiometer) derived net primary product (NPP) gridded at $8 \mathrm{~km}$, was used in the present study to detect presence of trend and inter annual variability in agriculture NPP over India. The product has been generated by University of Maryland USA using Global Production Efficiency Model (GloPEM). The model uses AVHRR images from the AVHRR Pathfinder Project and provides terrestrial net primary production and gross primary production product on the global scale in ten-day composite and summed annual products. GloPEM model is based on the production efficiency concept. The canopy absorbed photosynthetically active radiation (APAR) and the environmental factors controlling the utilization of APAR and autotrophic respiration rates of plants were used by the GloPEM model to compute the NPP (Prince and Goward, 1995; Goetz et al., 2000).

$$
\begin{gathered}
\mathrm{GPP}=\sum_{\mathrm{t}} \mathrm{FPAR} \times \mathrm{PAR} \times \varepsilon_{\mathrm{m}} \times \mathrm{f}(\mathrm{T}) \times \mathrm{f}(\mathrm{W}) \\
\mathrm{NPP}=\mathrm{GPP}-\left(\mathrm{P}_{\mathrm{g}}+\mathrm{P}_{\mathrm{m}}\right)
\end{gathered}
$$

Where,

GPP = Gross Primary Productivity over a unit area given time interval (t),

$\mathrm{PAR}=$ photosynthetically active radiations received over a unit area in time $(\mathrm{t})$,

FPAR $=$ fraction of PAR absorbed by vegetation over a unit area in time $(\mathrm{t})$,

$\varepsilon_{m}=$ maximum light use efficiency,

$\mathrm{f}(\mathrm{T})=$ temperature stress,

$\mathrm{f}(\mathrm{W})=$ water stress,

$\mathrm{P}_{\mathrm{g}}=$ plant growth respiration factor,

$\mathrm{P}_{\mathrm{m}}=$ plant maintenance respiration factor.

Time series terrestrial vegetation NPP over the Indian landmass was extracted by superimposing the India's administrative boundary over the global NPP images generated from 1981 to 2000. The pixel level linear trend analysis (Eq. 3) and decadal relative deviation (Eq. 4) in NPP values were estimated to detect trend (increase/decrease) and decadal variability in the time series NPP data. For this study, the annual mean NPP simulated using the GloPEM approach for the year 1981 to 2000 were used to compute the district level agricultural NPP of semi-arid regions of India.

$$
\mathrm{NPP}\left(\mathrm{gC} \mathrm{m}^{-2} \mathrm{yr}^{-1}\right)=\omega \mathrm{t}+\mathrm{c}
$$

Where, ' $\omega$ ' is slope, ' $c$ ' is the intercept of the model and ' $t$ ' indicates years from 1981 to 2000. Percentage change in ( $\triangle \mathrm{NPP}(\%)$ ) NPP were estimated for averaged 1981-1990 ( $\left.\mu_{1}\right)$ and 1991-2000 $\left(\mu_{2}\right)$ data to identify the regions of change (increasing and decreasing) in NPP over two decades (Figure 1b). Decadal Relative Deviation in percent (RD\%) was estimated as

$$
\Delta \operatorname{NPP}(\%)=\frac{\left(\mu_{2}-\mu_{1}\right)}{\mu_{1}} \times 100
$$

Using land use classification (Agrawal et al., 2003), the agricultural pixels in the country were masked and annual NPP for the pixels were extracted for the study period. Grid-wise decadal change ( $\triangle \mathrm{NPP}(\%)$ ) in agricultural NPP computed and regions which indicated positive and negative change in NPP were located. By using district administrative boundaries of India, district wise agricultural areas were marked and form these areas mean annual agricultural NPP were extracted. Figure 2 shows the pixel wise and the district wise decadal variation of agricultural NPP for the period of 20 years (19812000). The mean annual agricultural NPP per hectare was then multiplied by respective year's gross cultivated area of a district to get the total agricultural NPP for the respective year. These steps were repeated for each district to generate the district-wise total agricultural NPP for the period of 20 years.

District-wise gross cultivated area, gross irrigated area, area under high yielding varieties, fertilizer consumption (N, P, K) and agricultural mechanization data (number of tractors, number of electric and diesel operated irrigation pumps) were collected from the International Crop Research Institute for 
Semi-Arid Tropics (ICRISAT) district level database for India and annual state and district agricultural statistics reports.

\subsection{Statistical Analysis}

Influences and inter-relationships of direct and indirect anthropogenic factors governing agricultural NPP in semi-arid regions of India were assessed by using correlation and factor analysis. Correlation matrix $(\mathrm{p}<0.05)$ was used to explain the extent of correlation and inter-relationship between the agricultural NPP and the anthropogenic parameters. Factor analysis was carried out by using principal components extraction, which is then rotated for the ease of interpretation. The factor components with eigenvalues greater than 1 were considered for further analysis subjected to varimax rotation and Kaiser Normalization to reduce the parameters to highly correlated major factor component groups. Higher the communality estimates, higher the proportion of variability was explained by the factor component and hence, it would gain higher preference than other low communality estimates. The magnitude of the eigenvalues was used as a criterion for interpreting the relationship between anthropogenic attributes and factors. Anthropogenic attributes were assigned to a factor for which their eigenvalues was the highest (Shukla et al., 2006; Haque et al., 2007). This Redundancy Analysis maximizes the predictability of a set of variables from another (Shukla et al., 2006).

\section{RESULTS AND DISCUSSION}

\subsection{Gross Irrigated Area and Fertilizer Consumption}

Since 1981 to 2000, the total agricultural NPP of the study area was increased by $33.40 \%$. This is mainly because of the gross irrigated area has increased by $54.87 \%$, while the gross cultivated area increased slightly by $8.39 \%$ during the study period from 1981 to 2000. The fertilizer consumption of the study area has been tripled in the two decades. The Irrigated area and fertilizer consumption are the main anthropogenic factors which contributed the agricultural NPP.

Except Nashik and Osmanabad-Latur districts of Maharashtra, all the selected districts showed good correlation $(r>0.60)$ between the total agricultural NPP and the gross irrigated area. On the other hand, except Bhavnagar, Jamnagar and Surendranagar districts of Gujarat, all the selected districts showed good correlation ( $r>0.60)$ between the total agricultural NPP and the total fertilizer consumption.

The relatively lower correlation (Figure 3) between the district wise agricultural NPP and the gross irrigated area and the fertilizer consumption is due to the fact that though the irrigation and fertigation are the main factors contributing to the agricultural NPP but the soil physical properties and the climatic conditions govern the resultant agricultural productivity. Though all the districts come under the semi-arid region of India, the differences in the soil type, agro-climatic conditions, socio-economic factors and cropping patterns cause the lower correlation.

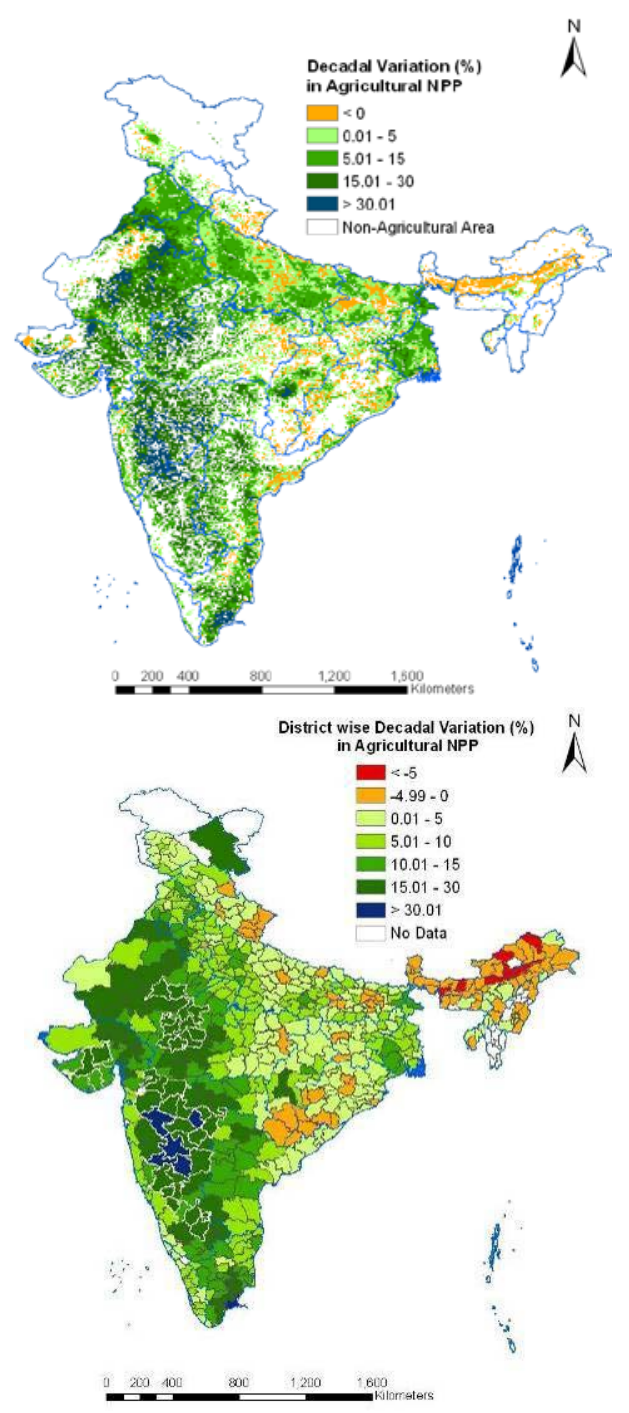

Figure 2. Decadal Variation (\%) in agricultural Net Primary Productivity (NPP) for the period of 1981-1990 to 1991-2000 (a) Pixel-wise and (b) District-wise

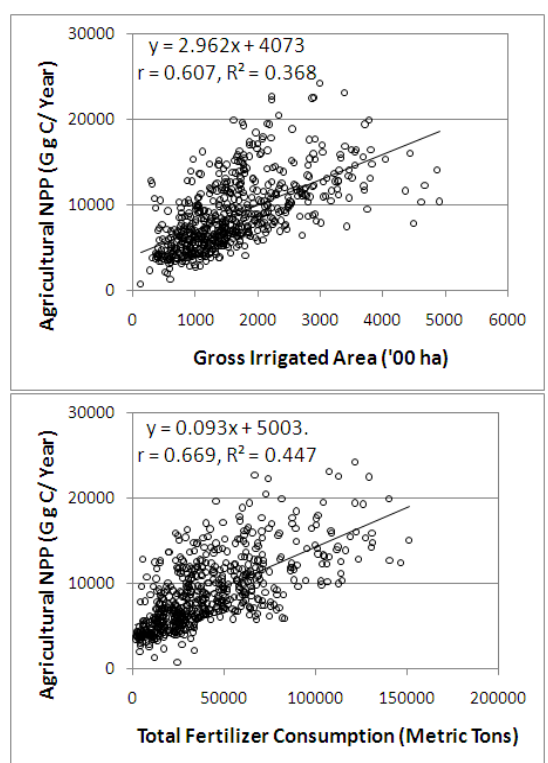

Figure 3. District wise annual agricultural NPP Vs annual total gross irrigated area and fertilizer consumption $(n=620, \mathrm{G} g=$ $\left.10^{9} \mathrm{~g}\right)$ 
The yearly total agricultural NPP of the study area showed a very good correlation with the total gross irrigated area $(\mathrm{r}=$ $\left.0.813, \mathrm{R}^{2}=0.668\right)$ and total fertilizer consumption $(\mathrm{r}=0.841$, $\left.\mathrm{R}^{2}=0.701\right)$ of the study region. Thus, the gross irrigated area and the fertilizer consumption are the two key anthropogenic factors contributed to the increase of agricultural NPP (Figure 4).
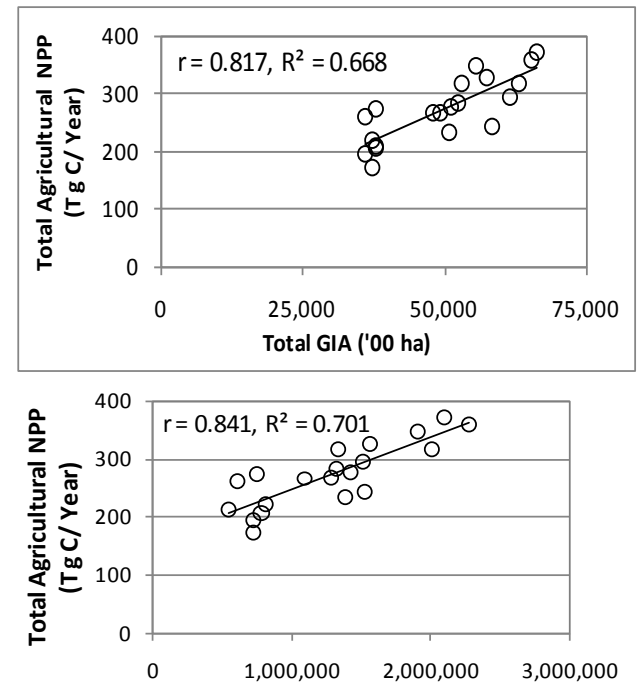

Total Fertilizer Consumption (Metric Tons)

Figure 4. Yearly total agricultural NPP of the study region Vs total gross irrigated area and fertilizer consumption of 20 years $(1981-2000)\left(\mathrm{n}=20, \mathrm{~T} \mathrm{~g}=10^{12} \mathrm{~g}\right)$

Nitrogen (N) is the major constituent of protein, nucleic acid and chlorophyll of a plant. The vegetative growth of plants is mainly governed by the availability of the Nitrogen Nutrient. Phosphorus (P) is required for the formation of ATP while, Potassium (K) although not an integral part of cell structure, it regulates many metabolic processes required for plant growth. In this study also, the correlation of yearly total agricultural NPP with $\mathrm{N}$ consumption was observed the highest $(\mathrm{r}=0.850$, $\left.\mathrm{R}^{2}=0.722\right)$ followed by the consumption of $\mathrm{P}\left(\mathrm{r}=0.806, \mathrm{R}^{2}=\right.$ $0.650)$ and $K\left(r=0.673, R^{2}=0.453\right)$.

The Indian soils are deficient in Nitrogen. Most of the Indian soils are low to medium in $\mathrm{P}$ and over time, $\mathrm{K}$ deficiency has also become widespread (FAO, 2005). So, the addition of essential primary nutrients $(\mathrm{N}, \mathrm{P}, \mathrm{K})$ showed strong positive correlation with the agricultural NPP (Figure 5).

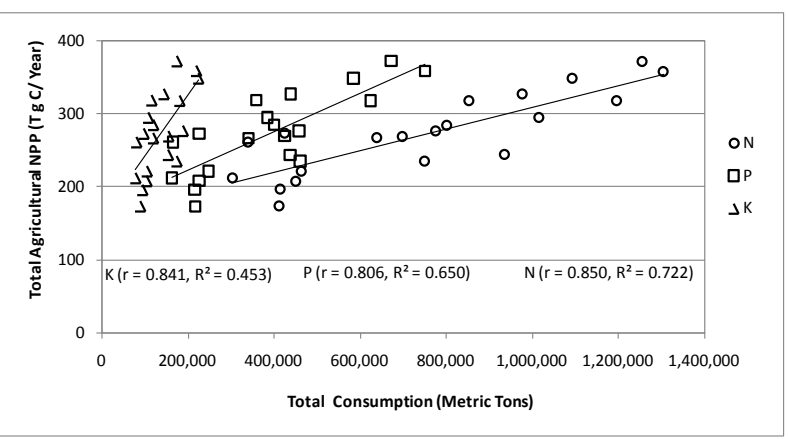

Figure 5. Yearly total agricultural NPP of the study region and its relation with the primary nutrients' $(\mathrm{N}, \mathrm{P}, \mathrm{K})$ comsumption $\left(\mathrm{T} \mathrm{g}=10^{12} \mathrm{~g}\right)$

\subsection{Agricultural Mechanization and its Relation with Total Agricultural NPP}

Mechanical and electrical energy is considered extensively as a part of agricultural mechanization (Singh, 2006). The increasing agricultural mechanization with farm tractors and other equipments eases the tillage operation and reduces the time required, hence more area can be covered in less time period. The mechanized farming is also helpful to bring the inaccessible area under cultivation.

Additionally, availability of irrigation pumps (electric and diesel operated) to harness the water from a tube well, dug well, farm pond, canal or river promote more intensive cropping by providing an assured and timely supply of water throughout the year.

The recent study conducted by Singh (2006) on the estimation of an extent of agricultural mechanization and its impact on production and economic factors of Indian agriculture revealed that irrigation (42\%), followed by power (32\%) and fertilizer (26\%) significantly contributed in increasing the yield. An increase in the agricultural mechanization increases the cropping intensity and the gross irrigated area (NCAER, 1981; Agarwal, 1984; Singh and De, 1999).

Here also, the correlation between the total agricultural NPP and the cropping intensity $\left(r=0.812, \mathrm{R}^{2}=0.660\right)$ and the percent of gross irrigated area to the cultivated area $(\mathrm{r}=0.804$, $\mathrm{R}^{2}=0.647$ ) confirms that the increase in the agricultural NPP is also driven by the extent of agricultural mechanization (Figure 6 and 7).

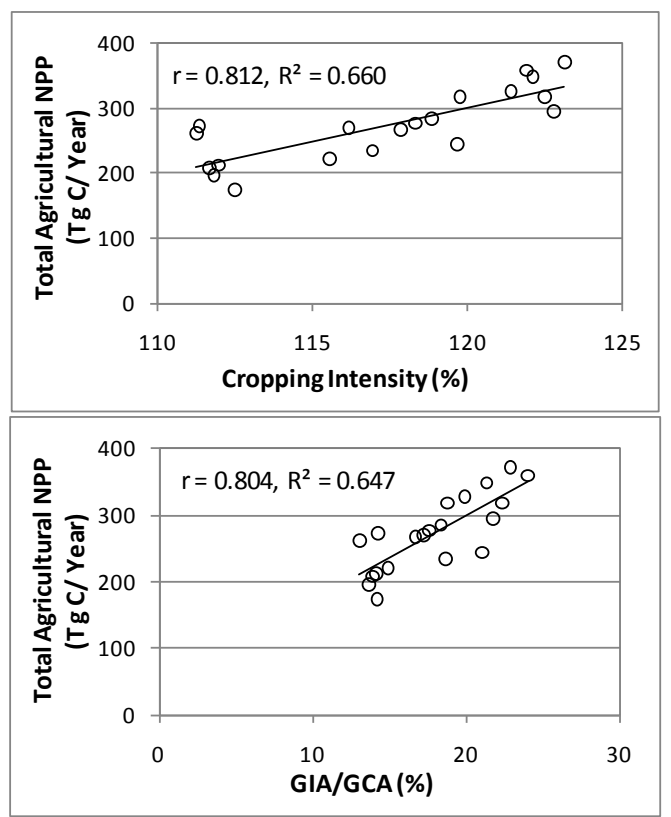

Figure 6. Total agricultural NPP of the study region Vs cropping intensity and percent of gross irrigated area to the gross cultivated area $\left(\mathrm{T} g=10^{12} \mathrm{~g}\right)$

Figure 7 shows the five yearly agricultural census data of number of tractors and irrigation pumps in use with the cropping intensity of the respective year. Since 1982 to 1997 , the number of tractors used was increased by $192.15 \%$, while the total number of irrigation pumps was increased by $74.76 \%$. Due to the access of rural electrification, the number of 
electricity operated irrigation pumps was increased by $116.7 \%$ in 15 years. From Figure 7 it is clear that the cropping intensity has been increasing with the increase in the use of farm tractors and irrigation pumps which ultimately contributed to the increase of agricultural NPP of the region.

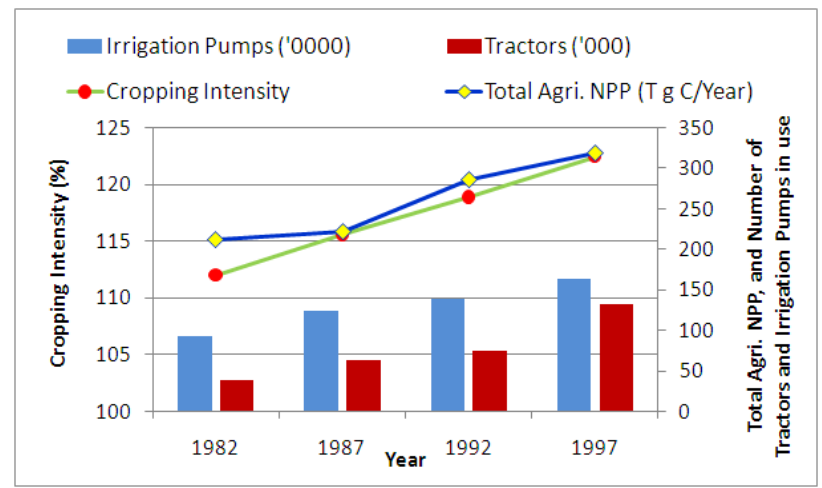

Figure 7. Increase in the agricultural NPP and cropping intensity with increase in the number of irrigation pumps and farm tractors in use $\left(\mathrm{T} \mathrm{g}=10^{12} \mathrm{~g}\right)$

\subsection{Influence and Inter-relationship of Anthropogenic Activities Governing the Agricultural Net Primary Productivity}

The five yearly agricultural mechanization data and the corresponding years' NPP and other anthropogenic data (irrigation and fertilizer) were analyzed. Table 2 shows the correlation matrix among the agricultural mean and total NPP with the anthropogenic factors to assess their influence and inter-relationships with agricultural NPP. Of 120 pairs in the correlation matrix, 83 pairs showed significant correlation among them.

The positive correlation $(\mathrm{p}<0.05)$ was observed between the total agricultural NPP and the gross cultivated area, gross irrigated area, fertilizer consumption followed by the number of tractors and irrigation pumps used. The cropping index and irrigation index both showed a positive relationship with the mean agricultural NPP. The increase in the area cultivated under High Yielding Varieties (HYV) of crops showed significant positive correlation $(\mathrm{p}<0.05)$ with agricultural NPP and the other anthropogenic factors.

A negative relationship $(\mathrm{p}<0.01)$ of total agricultural NPP with diesel operated irrigation pump is due to the extensive rural electrification introduced in late 80's, encouraged the adoption of electrically operated irrigation pumps. Hence, diesel operated irrigation pump was not directly considered as a parameter in the further factor analysis, but included in the total irrigation pumps.

A significant positive relationship was observed between the irrigation index (GIA/GCA) and the irrigation pumps (diesel, electrical and total). A positive relationship $(\mathrm{p}<0.05)$ was also found between cropping index and mean agricultural NPP and gross irrigated area.

From Table 2, the anthropogenic factors which showed the significant correlation with the total NPP were selected for the factor analysis. Table 3 shows that first three factor components with eigenvalues $>1$, accounted for $83 \%$ of the variability in anthropogenic factors governing the agricultural NPP. Factor analysis reduced the 10 anthropogenic factors into three groups which explained $83 \%$ of the total variability. Table 4 represents the proportion of variance and community estimates for direct and indirect anthropogenic factors governing the agricultural NPP.

The first factor component (FC1) which includes consumption of primary fertilizers $(\mathrm{N}, \mathrm{P}, \mathrm{K})$ and total fertilizers (primary + secondary) accounted about $37 \%$ of the total variance (community estimates $>0.82$ ). The second factor component (FC2) which includes mainly the gross irrigated area and the mechanization in terms of Irrigation pumps and farm tractors explained about $26 \%$ of the total variance (community estimates between 0.70 to 0.80 ). While, the third factor component (FC3) which includes gross cultivated area and the area under high yielding crop varieties contributed about $21 \%$ of the total variance (community estimates for GCA $=0.784$ and $\mathrm{HYV}=0.824$ ).

Table 2. Correlation matrix among the agricultural mean and total NPP with the anthropogenic factors to assess their influences and inter-relationships with agricultural NPP

\begin{tabular}{|c|c|c|c|c|c|c|c|c|c|c|c|c|c|c|c|}
\hline & Mean_NPP & NPP_T & GIA & GCA & $\mathrm{N}$ & $\mathrm{P}$ & $\mathrm{K}$ & Total_F & Tractors & Pumps_D & Pumps_E & Pumps_T & $\mathrm{CI}$ & II & HYV \\
\hline Mean_NPP & 1 & & & & & & & & & & & & & & \\
\hline NPP_T & $.365^{* *}$ & 1 & & & & & & & & & & & & & \\
\hline GIA & $.281^{* *}$ & $.486^{* *}$ & 1 & & & & & & & & & & & & \\
\hline GCA & .078 & $.705^{* *}$ & $.437^{* *}$ & 1 & & & & & & & & & & & \\
\hline $\mathrm{N}$ & $.388^{* *}$ & $.490^{* *}$ & $.424^{* *}$ & $.389^{* *}$ & 1 & & & & & & & & & & \\
\hline $\mathrm{P}$ & $.410^{* *}$ & $.447^{* *}$ & $.390^{* *}$ & $.346^{* *}$ & $.740^{* *}$ & 1 & & & & & & & & & \\
\hline K & $.231^{* *}$ & $.469^{* *}$ & $.296^{* *}$ & $.449^{* *}$ & $.584^{* *}$ & $.508^{* *}$ & 1 & & & & & & & & \\
\hline Total_F & $.395^{* *}$ & $.504^{* *}$ & $.413^{* *}$ & $.402^{* *}$ & $.913^{* *}$ & $.799^{* *}$ & $.628^{* *}$ & 1 & & & & & & & \\
\hline Tractors & $.398^{* *}$ & $.355^{* *}$ & $.471^{* *}$ & $.231^{* *}$ & $.500^{* *}$ & $.496^{* *}$ & $.325^{* *}$ & $.508^{* *}$ & 1 & & & & & & \\
\hline Pumps_D & -.094 & $-.122^{*}$ & $.150^{* *}$ & -.065 & -.036 & -.033 & $-.159^{* *}$ & -.053 & $.181^{* *}$ & 11 & & & & & \\
\hline Pumps_E & $.216^{* *}$ & $.424^{* *}$ & $.369^{* *}$ & $.377^{* *}$ & $.451^{* *}$ & $.354^{* *}$ & $.419^{* *}$ & $.440^{* *}$ & $.305^{* *}$ & -.075 & 11 & & & & \\
\hline Pumps_T & $.166^{* *}$ & $.235^{* *}$ & $.407^{* *}$ & $.220^{* *}$ & $.422^{* *}$ & $.380^{* *}$ & $.230^{* *}$ & $.398^{* *}$ & $.420^{* *}$ & $.355^{* *}$ & $.569^{* *}$ & 1 & & & \\
\hline CI & $.233^{* *}$ & .068 & $.114^{*}$ & -.046 & .044 & .103 & -.103 & .048 & .015 & -.105 & .001 & -.029 & 1 & & \\
\hline II & $.294^{* *}$ & .031 & $.471^{* *}$ & -.093 & $.143^{*}$ & $.163^{* *}$ & -.021 & $.129^{*}$ & $.339^{* *}$ & $.219^{* *}$ & $.130^{*}$ & $.259^{* *}$ & $.165^{* *}$ & 1 & \\
\hline HYV & $.148^{*}$ & $.508 * *$ & $.297 * *$ & $.520 * *$ & $.445^{* *}$ & $.344^{* *}$ & $.472 * *$ & $.436^{* * *}$ & $.188 * *$ & $-.217^{* *}$ & $.435^{* *}$ & $.177^{* *}$ & -.009 & -.063 & 1 \\
\hline
\end{tabular}

** Correlation is significant at the 0.01 level, * Correlation is significant at the 0.05 level 
Table 3. Eigenvalue, proportion and cumulative variance explained by factor analysis using correlation matrix of direct and indirect anthropogenic factors governing the agricultural NPP

\begin{tabular}{|c|c|r|r|}
\hline \multirow{2}{*}{$\begin{array}{c}\text { Factor } \\
\text { Component }\end{array}$} & \multicolumn{3}{|c|}{ Rotation Sums of Squared Loadings } \\
\cline { 2 - 4 } & Eigenvalue & \% of Variance & Cumulative \% \\
\hline 1 & 3.677 & 36.78 & 36.78 \\
2 & 2.564 & 25.64 & 62.42 \\
3 & 2.063 & 20.63 & 83.05 \\
\hline
\end{tabular}

Table 4. Proportion of variance and communality estimates for direct and indirect anthropogenic factors governing the agricultural NPP (varimax rotation and Kaiser Normalized, Principal component method)

\begin{tabular}{|c|c|c|c|c|c|c|c|}
\hline \multirow{3}{*}{$\begin{array}{l}\text { Anthropogenic } \\
\text { factors } \\
\text { governing } \\
\text { agricultural NPP }\end{array}$} & \multirow{2}{*}{\multicolumn{3}{|c|}{$\begin{array}{c}\text { Rotated Component Matrix } \\
\text { Factor Component }\end{array}$}} & \multirow{2}{*}{\multicolumn{3}{|c|}{$\begin{array}{c}\text { Score Coefficient Matrix } \\
\text { Factor Component }\end{array}$}} & \multirow{3}{*}{$\begin{array}{l}\text { Communalities } \\
\text { estimates }\end{array}$} \\
\hline & & & & & & & \\
\hline & FC1 & $F C 2$ & FC3 & FC1 & FC2 & FC3 & \\
\hline Total_F & .904 & .315 & .253 & .300 & -.066 & -.052 & .981 \\
\hline $\mathrm{N}$ & .853 & .370 & .250 & .263 & -.017 & -.056 & .927 \\
\hline $\mathrm{P}$ & .880 & .308 & .174 & .305 & -.048 & -.105 & .899 \\
\hline K & .847 & .008 & .323 & .335 & -.271 & .076 & .823 \\
\hline GIA & .323 & .733 & .243 & -.075 & .356 & -.036 & .701 \\
\hline Pumps_T & .128 & .869 & .163 & -.185 & .511 & -.086 & .797 \\
\hline Pumps_E & .194 & .673 & .549 & -.180 & .284 & .230 & .793 \\
\hline Tractors & .594 & .649 & -.034 & .127 & .292 & -.276 & .775 \\
\hline GCA & .184 & .203 & .842 & -.125 & -.088 & .548 & .784 \\
\hline HYV & .308 & .157 & .840 & -.055 & -.148 & .532 & .824 \\
\hline $\begin{array}{l}\% \text { of Total Variance } \\
\text { Explained }\end{array}$ & 36.78 & 25.64 & 20.63 & 36.78 & 25.64 & 20.63 & \\
\hline
\end{tabular}

The rotation convergent in 5 iterations. Variables in bold letters indicated the major contributors in the group.

FC1 was directly related to the macro and micro 'nutrient application' which explained $37 \%$ of the total variance. The FC2 represented the 'irrigation potential and agricultural mechanization' which explained $26 \%$ of total variance. The FC3 accounted for 'cultivated area and area under high yielding crop varieties' which explained $21 \%$ of total variance

\section{CONCLUSIONS}

The present study demonstrates the positive role of human interventions through increasing adaptation of agricultural mechanization, high yielding crop varieties and fertilizer use in the semi-arid region of India.

Increase in the gross irrigated area and fertilizer consumption has considerably enhanced agricultural NPP of the region. Variability in the correlation between agricultural NPP and irrigation and fertilizer use is mainly due to variations in soil type, agro-climatic conditions, socio-economic factors and cropping patterns. Promoting the awareness for tube-well refilling activities during rainy season could help the region to harness more water and use it for agricultural activities for the rest of the year.

The extent of anthropogenic activities in terms of agricultural mechanization positively influences the growth of the agricultural NPP in the districts of the semi-arid region of India. Agricultural mechanization could help to increase the agricultural NPP by enabling farmers to manage the time and water resources optimally hence allowing to grow an extra crop or to develop more area under the existing crop with available inputs.

The level of mechanization Index of the country is still very low. Thus, there is a plenty of scope exists to promote agricultural mechanization which ultimately contributes to the increase in the agricultural net productivity of the area. Also, an integrated nutrient management approach along with soil testing is required to facilitate a balanced use of macro and micro fertilizers for optimum results.

Thus, the sustainable agricultural mechanization development, optimum utilization of available irrigation water, and following advanced cultivation methods such as crop rotations, integrated nutrient management and integrated pest management practices are some of the assured ways to tackle through the most likely effects of climate change faced by the semi-arid regions of India.

\section{ACKNOWLEDGEMENTS}

This research was carried out under ISRO-GBP Geosphere Biosphere Programme, Energy and Mass Exchange in Vegetation System. The authors are grateful to the International Crop Research Institute for Semi-Arid Tropics (ICRISAT) for providing all the agricultural and anthropogenic data for the study. Authors are also thankful to Shri. A. S. Kiran Kumar, Director, Space Applications 
Centre (SAC), Indian Space Research Organization (ISRO), India. One of the authors (Madhav D. Gholkar) wishes to acknowledge the fellowship grant endorsed by SAC and apt help of Mr. Ravi Upadhyay in GIS analysis.

\section{REFERENCES}

Agarwal, B., 1984. Tractors, tube wells and cropping intensity in the Indian Punjab. Journal of Developmental Studies 20(4):290-302.

Aggarwal, P.K., Mall, R.K., 2002. Climate change and rice yields in diverse agro-environments of India II Effect of uncertainties in scenarios and crop models on impact assessment. Climatic Change 52(3):331-343.

Agrawal, S., Joshi, P.K., Shukla, Y., Roy, P.S., 2003. SPOT VEGETATION multi temporal data for classifying vegetation in south central Asia. Current Science, 84:14401448.

Ahlström, A., Schurgers, G., Arneth, A., Smith, B., 2012. Robustness and uncertainty in terrestrial ecosystem carbon response to CMIP5 climate change projections. Environmental Research Letters 7(4):1748-9326.

Bala, G., Joshi. J., Chaturvedi, R.K., Gangamani, H.V., Hashimoto, H., Nemani, R. 2013. Trends and Variability of AVHRR-Derived NPP in India. Remote Sensing, 5(2):810829.

CED 2011. Centre for Education and Documentation - Ecoregional Notes on Climate Change and Semi-Arid Regions. A Climate Education booklet.

Chhabra, A., Dadhwal, V.K., 2004. Estimating terrestrial net primary productivity over India using satellite data. Current Science, 86:269-271.

DIA 1997. Directory of Indian Agriculture, Ministry of Agriculture, Government of India.

FAO 2005. Fertilizer use by crop in India - Food and Agricultural organization. First version, FAO, Rome.

Goetz, S.J., Prince, S.P., Smell. J., Gleason, A.C.R., 2000. Interannual variability of global terrestrial primary production: Results of a model driven with global satellite observations. Journal of Geophysical Research, 105(D15), 20077-20091.

Haque, A.A.M., Jayasuriya, H.P.W., Salokhe, V.M., Tripathi, N.K., Parkpian, P., 2007. Assessment of Influential Soil Properties by GIS and Factor Analysis for Irrigated Rice Production of Bangladesh: A Case Study. Agricultural Engineering International: the CIGR E-journal. Manuscript LW 07 022. Vol. IX. November, 2007.

Hemming, D., Betts, R., Collins, M., 2013. Sensitivity and uncertainty of modeled terrestrial net primary productivity to doubled $\mathrm{CO}_{2}$ and associated climate change for a relatively large perturbed physics ensemble. Agricultural and Forest Meteorology 170:79-88.

IPCC 2007. Intergovernmental Panel on Climate Change Climate Change 2007: Synthesis Report.

Jewitt, S., Baker, K., 2012. Risk, wealth and agrarian change in India. Household-level hazards vs. late-modern global risks at different points along the risk transition. Global Environmental Change 22(2):547-557.

Keen, A., Hall, N., Soni, P., Gholkar, M.D., Cooper, S., Ferdous, J., 2013. A review of the tractive performance of wheeled tractors and soil management in lowland intensive rice production. Journal of Terramechanics 50(1):45-62.

NATCOM 2004. India's first National Communication to UNFCCC. MoEF, Government of India.
Nayak, R.K., Patel, N.R., Dadhwal, V.K., 2013. Interannual variability and climate control of terrestrial net primary productivity over India. Int. J. Climatol. 33(1):132142.

NCAER 1981. Implication of tractorisation for farm employment, productivity and income. National Council of Applied Economic Research, Parisila Bhawan, New Delhi. NICA 2011. National Initiative on Climatic Resilient Agriculture (http://www.nicraicar.in/nicrarevised/index.php/component/content/article?lay out=edit\&id=195) Cited on: 31 ${ }^{\text {st }}$ January 2014.

O’Brien, K., Leichenkob, R., Kelkar, U., Venema, H., Aandahl, G., Tompkins, H., Javed, A., Bhadwal, S., Barg, S., Nygaard, L., West, J., 2004. Mapping vulnerability to multiple stressors: climate change and globalization in India. Global Environmental Change 14(4):303-313.

Prasad, V.K., Badarinth, K.V.S., 2004. Land use changes and trends in human appropriation of aboveground net primary production (HANPP) in India (1961-1998). Geogr J. 170(1):51-63.

Prince, S.D., Goward, S.J., 1995. Global primary production: A remote sensing approach. Journal of Biogeography, 22: 316-336.

Shukla, M.K., Lal, R., Ebinger, M., 2006. Determining soil quality indicators by factor analysis. Soil and Tillage Research 87(2):194-204.

Singh, G., De, D. 1999. Quantification of a mechanization indicator for Indian agriculture. Applied Engineering in Agriculture 15(3):197-204.

Singh, G., 2006. Estimation of a Mechanization Index and Its Impact on Production and Economic Factors - a Case Study in India. Biosystems Engineering 93(1):99-106.

Singh, R.P., Rovshan, S., Goroshi, S.K., Panigrahy, S., Parihar, J.S., 2011. Spatial and temporal variability of Net Primary Productivity (NPP) over terrestrial biosphere of India using NOAA-AVHRR based GloPEM model. J. Ind. Soc. Remote Sens. 39(3):345-353.

Soni, P., Ou, Y. 2012. Agricultural Mechanization at a Glance Selected Country Studies in Asia on Agricultural Machinery Development. Centre for Sustainable Agricultural mechanization.

http://www.unapcaem.org/publication/Pub_AM2010.htm Cited on 1 December 2013.

\section{ABBREVIATIONS}

$\begin{array}{ll}\text { Mean_NPP } & \text { Mean agricultural NPP } \\ \text { NPP_T } & \text { Total agricultural NPP } \\ \text { GIA } & \text { Gross irrigated area } \\ \text { GCA } & \text { Gross cultivated area } \\ \text { NIA } & \text { Net irrigated area } \\ \text { NCA } & \text { Net cultivated area } \\ \text { CI } & \text { Cropping intensity (GCA/NCA) } \\ \text { II } & \text { Irrigation index (GIA/GCA) } \\ \text { Pumps_D } & \text { Diesel operated irrigation pumps } \\ \text { Pumps_E } & \text { Electricity operated irrigation pumps } \\ \text { Pumps_T } & \text { Total irrigation pumps } \\ \text { N } & \text { Nitrogen fertilizer consumption } \\ \text { P } & \text { Phosphorous fertilizer consumption } \\ \text { K } & \text { Potassium fertilizer consumption } \\ \text { Total_F } & \text { Total fertilizer consumption } \\ \text { HYV } & \text { High yielding varieties }\end{array}$

